\title{
Analisis pengaruh pertumbuhan ekonomi, inflasi dan suku bunga terhadap pertumbuhan UMKM di Provinsi Jambi
}

\author{
Dian Romadhoni*; Amril; Emilia \\ Prodi Ekonomi Pembangunan Fak.Ekonomi dan Bisnis Universitas Jambi \\ *E-mail koresponden: Romadondian@gmail.com
}

\begin{abstract}
This study entitled the analysis of economic growth, inflation, and interest rates on the development of MSMEs in Jambi Province. To analyze Indonesia's economic growth, inflation, and interest rates on the number of MSME business units in Jambi Province in 2003 - 2018. The analytical method used in this study is a descriptive qualitative analysis and quantitative analysis. Data processing is done by using multiple linear regression. The estimation results using the statistical $f$ test show that all variables, namely economic growth, inflation, and Indonesian interest rates, together affect the development of MSMEs in Jambi Province, with statistical t-tests showing that economic growth variables have a significant effect on MSME growth in Jambi Province, inflation has a significant impact on the growth of MSMEs in Jambi Province, and Indonesian interest rates have a substantial impact on the development of MSMEs in Jambi Province.
\end{abstract}

Keywords: Economic growth, Inflation, Interest rates, MSME growth

\begin{abstract}
Abstrak
Penelitian ini berjudul analisis pengaruh pertumbuhan ekonomi, inflasi dan suku bunga terhadap pertumbuhan umkm di Provinsi Jambi. Untuk menganalisis pengaruh pertumbuhan ekonomi, inflasi dan suku bunga Indonesia terhadap jumlah unit usaha UMKM di Provinsi Jambi Tahun 2003 - 2018. Metode analisis yang digunakan dalam penelitian ini analisis deskriptif kualitatif dan analisis kuantitatif. Pengolahan data dilakukan dengan menggunakan regresi linier berganda. Hasil estimasi menggunakan uji f statistik menunjukan bahwa semua variabel yaitu pertumbuhan ekonomi, inflasi dan suku bunga Indonesia secara bersama - sama berpengaruh terhadap pertumbuhan UMKM di Provinsi Jambi, dengan uji t statistik menunjukan bahwa variabel pertumbuhan ekonomi berpengaruh signifikan terhadap pertumbuhan UMKM di Provinsi Jambi, inflasi berpengaruh signifikan terhadap pertumbuhan UMKM di Provinsi Jambi dan suku bunga Indonesia berpengaruh signifikan terhadap pertumbuhan UMKM di Provinsi Jambi.
\end{abstract}

Kata kunci: Pertumbuhan ekonomi, Inflasi, Suku bunga, Pertumbuhan UMKM

\section{PENDAHULUAN}

Usaha mikro kecil dan menengah (UMKM) di negara berkembang hampir selalu merupakan kegiatan ekonomi yang terbesar dalam jumlah dan kemampuannya dalam menyerap tenaga kerja. Sektor ini dapat tetap menjadi tumpuan bagi stabilitas ekonomi 
nasional. Sehingga perannya diharapkan dapat menciptakan kesejahteraan kepada masyarakat Indonesia. Kondisi yang kurang menguntungkan tersebut diperlukan suatu upaya untuk mengembangkan UMKM, salah satunya yaitu mampu mningkatkan pembangunan ekonomi (Azirin, 2004).

Pertumbuhan UMKM akan menimbulkan dampak positif yang berpotensial dan menjaga stabilitas perekonomian, yang mampu mengatasi beberapa persoalan pokok seperti pemerataan dalam distribusi pendapatan, dan pembangunan ekonomi. Maka strategi pembangunan UMKM harus sebagai sektor yang kompetitif sehingga pengembangannya perlu mempertajam pilihan pada sektor tertentu. Sehingga hasilnya dapat menimbulkan dampak positif terhadap pembangunan dan pertumbuhan ekonomi selanjutnya (Sutrisno, 2004).

Pengembangan UMKM diyakini akan memperkuat ekonomi nasional, dengan beberapa pertimbangan bahwa UMKM pada umumnya berbasis pada sumber sumberdaya ekonomi lokal dan tidak bergantung pada impor, serta hasilnya mampu diekspor karena keunikannya. Perekonomian Indonesia akan memiliki fondasi yang kuat, jika UMKM menjadi pelaku utama yang produktif dan berdaya saing dalam perekonomian nasional. Untuk itu, pembangunan usaha mikro, kecil, dan menengah perlu menjadi prioritas utama pembangunan ekonomi nasional dalam jangka panjang (Setyawati, 2009).

Peranan UMKM sangat strategis, karena potensinya yang besar dalam menggerakkan kegiatan ekonomi masyarakat dan sekaligus menjadi tumpuan sumber pendapatan sebagian besar masyarakat dalam meningkatkan kesejahteraannya.

Data 5 tahun terakhir menunjukan perkembangan yang sangat rendah yaitu ratarata 0.38 persen bagi pemerataan pembangunan dalam sektor industry bahwa sektor ini dapat menjadi tumpuan bagi perekonomian di Provinsi Jambi, hal ini dikarenakan UMKM mampu bertahan dibandingkan dengan usaha besar yang cenderung mengalami keterpurukan. UMKM di Provinsi Jambi dalam beberapa tahun terakhir mengalami peningkatan, pada tahun 2013 UMKM di sebanyak 81.552 unit, pada tahun 2017 meningkat sebanyak 82.700 unit atau 0.27 persen dan pada tahun 2018 meningkat menjadi 83.150 unit atau 0.54 persen (Badan Pusat Statistik, 2019).

Ada beberapa factor yang mempengaruhi perkembangan UMKM yaitu pertumbuhan ekonomi. Hal tersebut dibuktikan dengan selain semakin bertambahnya jumlah UMKM maka berkontribusi terhadap pertumbuhan ekonomi di Provinsi Jambi. Secara umum peranan UMKM dalam pembentukan Produk Domestik Regional Bruto (PDRB) memiliki keunggulan dalam bidang yang memanfaatkan sumberdaya alam dan padat karya, seperti : pertanian tanaman pangan, perkebunan, peternakan, perikanan, perdagangan, dan restoran. UMKM yang mengalami peningkatan dalam jumlah unit usaha cenderung meningkatkan jumlah memproduksi barang konsumsi dan jasa-jasa yang mampu menompang pertumbuhan ekonomi di Provinsi Jambi.

Data 5 tahun terakhir pertumbuhan ekonomi di Provinsi Jambi rata - rata meningkat sebesar 5.04 persen, pertumbuhan ekonomi pada tahun 2014 sebesar 7.18 persen, pada tahun 2015 pertumbuhan ekonomi meningkat sebesar 4.15 persen, serta 2016 kembali meningkat menjadi 4.52 persen, pada tahun 2017 meningkat menjadi 4.64 persen dan pada tahun 2018 meningkat menjadi 4.71 persen (Badan Pusat Statistik, 2019).

Pertumbuhan ekonomi menunjukkan berfluktuasi akan tetapi cenderung meningkat rata - rata sebesar 5.61 persen, kondisi ini menunjukkan trend perekonomian 
Provinsi Jambi yang positif. Akan tetapi, laju pertumbuhan ekonomi tidak menunjukkan perlambatan tiap tahunnya. Hal ini disebabkan karena adanya krisis keuangan nasional yang menyebabkan Provinsi Jambi merasakan dampaknya. Terlepas dari krisis keuangan nasional tersebut, Provinsi Jambi mulai mengalami peningkatan laju pertumbuhan ekonominya kembali. Jika kondisi ini tidak segera diperbaiki, maka dapat menimbulkan perlambatan ekonomi di Provinsi Jambi.

Pertumbuhan ekonomi merupakan faktor utama dalam meningkatkan pembangunan di Provinsi Jambi, dalam meningkatkan pembangunan tersebut di perlukannya peningkatan dari hasil produksi salah satunya dengan pertumbuhan UMKM yang ada di Provinsi Jambi, dalam hubungan proses input output ini suatu industri harus melalui proses dengan berbagai mata rantai yang menunjukan tahap tahap proses dimana hasil produksi pada tahap awal merupakan masukan bagi tahap produksi dalam menambah nilai guna (Firmansyah, 2001).

Faktor lainnya yang mempengaruhi UMKM adalah inflasi menjadi kunci kesejahteraan masyarakat karena mempengaruhi daya beli. Semakin tinggi inflasi maka daya beli masyarakat dapat menurun sedangkan jika inflasi menurun maka daya beli masyarakat dapat bertumbuh, Pengembangan UMKM diharapkan akan meningkatkan stabilitas ekonomi karena menggunakan bahan baku lokal dan memiliki potensi ekspor sehingga akan membantu menstabilkan kurs rupiah dan tingkat inflasi. Pembangunan UMKM akan menggerakkan sektor riil karena UMKM umumnya memiliki keterkaitan industri yang cukup tinggi. Sektor UMKM diharapkan akan menjadi tumpuan pengembangan sistem perbankan yang kuat dan sehat pada masa mendatang.

Data 5 tahun terakhir menunjukan rata - rata tingkat inflasi di Provinsi Jambi sebesar 5.05 persen, tingkat inflasi yang mengalami fluktuasi setiap tahunnya pada tahun 2013 inflasi sebesar 7.59 persen, menurun pada tahun 2014 sebesar 6.63 persen, pada tahun 2015 inflasi mencapai 5.29 persen, menurun kembali pada tahun 2016 sebesar 3.57 persen, pada tahun 2017 meningkat kembali sebesar 4.24 persen, dan pada tahun 2018 meningkat kembali sebesar 3.02 persen (Bank Indonesia, 2019).

Perkembangan potensi Usaha Mikro, Kecil, dan Menengah (UMKM) tidak terlepas dari dukungan perbankan dalam penyaluran kredit kepada UMKM. Setiap tahun kredit kepada UMKM mengalami pertumbuhan dan secara umum pertumbuhannya lebih tinggi dibanding total kredit perbankan. Kredit UMKM adalah kredit kepada debitur usaha mikro, kecil dan menengah yang memenuhi definisi dan kriteria usaha mikro, kecil dan menengah sebagaimana diatur dalam UU No. 20 Tahun 2008 Tentang UMKM. Berdasarkan UU tersebut, UMKM adalah usaha produktif yang memenuhi kriteria usaha dengan batasan tertentu kekayaan bersih dan hasil penjualan tahunan.

Data 5 tahun terakhir menunjukan rata - rata tingkat suku bunga sebesar 6.25 persen, tingkat SBI yang mengalami fluktuasi setiap tahunnya pada tahun 2013 SBI sebesar 6.48 persen, meningkat pada tahun 2014 sebesar 7.54 persen, pada tahun 2015 SBI menurun mencapai 7.52 persen, menurun kembali pada tahun 2016 sebesar 5.50 persen, pada tahun 2017 menurun kembali sebesar 4.75 persen dan pada tahun 2018 menurun kembali sebesar 5.75 persen (Bank Indonesia, 2019).

Kondisi suku bunga umumnya masih tetap tinggi, apalagi bunga pinjaman usaha mikro kecil dan menengah (UMKM) tetap bertahan di kisaran 20\% lebih per tahun. Harusnya khusus kredit UMKM, Bank Indonesia bersama pemerintah perlu memikirkan adanya subsidi bunga di tengah melemahnya pertumbuhan ekonomi saat ini. Pasalnya, 
dengan suku bunga khusus misalnya tidak lebih dari $15 \%$ per tahun, akan mendorong pengusaha UMKM bisa survive dan menjadi pilar pendukung ekonomi nasional.

Adanya UMKM diharapkan dapat membantu mendorong pertumbuhan ekonomi di Provinsi Jambi melalui kontribusi sumbangan UMKM terhadap pertumbuhan ekonomi. Banyaknya jumlah UMKM menunjukkan adanya trend peningkatan jumlah tiap tahunnya seharusnya dapat memberikan sumbangan yang tinggi terhadap perekonomian, namun kenyataanya dunia usaha tidak terlepas dari turbulensi dan resiko keuangan, dalam perkembangan UMKM resiko menjadi lebih tinggi karena aset yang kecil membuat dana usaha habis dalam pembayaran kewajiban, terutama saat inflasi dan suku bunga tinggi. Kenaikan inflasi dan suku bunga akan membuat biaya keuangan dalam usaha semakin tinggi, sehingga dapat berpengaruh pada kelangsungan usaha. Selain itu, permodalan merupakan tantangan yang paling penting dalam usaha pengembangan UMKM. Faktor modal bagi UMKM menjadi penting, sebab UMKM seringkali mendapatkan peluang usaha yang cukup besar. Namun, kondisi permodalan yang minim membuat UMKM tidak dapat mengembangkan usahanya lebih jauh lagi. Melihat kondisi di Provinsi Jambi dimana sektor UMKM merupakan usaha yang dominan dengan jumlah yang cukup tinggi setiap tahunnya.

\section{METODE}

\section{Metode analisis data}

Menganalisis pengaruh pertumbuhan ekonomi, inflasi dan suku bunga Indonesia terhadap pertumbuhan unit usaha UMKM di Provinsi Jambi Tahun 2003 - 2018 menggunakan metode analisis regresi linier berganda adapun rumus sebagai berikut (Gujarati, 2003):

$$
\mathrm{UMKM}=\beta_{0}+\beta_{1} \mathrm{PE}+\beta_{2} \mathrm{INF}+\beta_{3} \mathrm{SBI}+\varepsilon
$$

Keterangan :

\begin{tabular}{|c|c|}
\hline UMKM & $=$ Pertumbuhan UMKM (\%) \\
\hline$\beta_{\circ}$ & $=$ Konstanta regresi \\
\hline$\beta 1-\beta 3$ & $=$ Koefesien regresi \\
\hline $\mathrm{PE}$ & $=$ Pertumbuhan ekonomi $(\%)$ \\
\hline INF & $=\operatorname{Inflasi}(\%)$ \\
\hline SBI & $=$ Suku Bunga Indonesia (\%) \\
\hline$\varepsilon$ & = Kesalahan pengganggu \\
\hline
\end{tabular}

\section{Pengujian hipotesis}

Menguji parameter yang diduga sebagai petunjuk dari nilai-nilai yang dihasilkan maka dipakai uji statistik sebagai berikut:

Uji F, digunakan untuk menguji seberapa besar pengaruh tingkat signifikansi variabel bebas ( independent ) terhadap variabel terikat ( dependent ) secara bersama-sama.

Nilai F hitung diperoleh dengan rumus :

$$
\mathrm{F}=\frac{\mathrm{R}^{2} /(\mathrm{K}-1)}{\left(1-\mathrm{R}^{2}\right) /(\mathrm{n}-\mathrm{k})}
$$

Dimana :

$\mathrm{F}=\mathrm{F}$ hitung

$\mathrm{R}^{2}=$ Koefesien determinasi 
$\mathrm{K}=$ Jumlah variabel independent (bebas )

$\mathrm{N}$ = Jumlah sample

Nilai $F$ hitung dibandingkan nilai $F$ table pada tingkat derajat kebebasan (df) dengan tingkat keyakinan tertentu dengan keputusan sebagai berikut :

Apabila F hitung $>$ F tabel bearti Ho ditolak,artinya terdapat pengaruh yang nyata antara faktor-faktor produksi. Dan apabila $\mathrm{F}$ hitung $<\mathrm{F}$ tabel bearti Ho diterima, artinya tidak terdapat hubungan yang nyata antara faktor-faktor produksi.Uji $t$, digunakan untuk mengetahui secara persial seberapa besar pengaruh tingkat signifikansi variabel bebas (independent) terhadap variabel terikat (dependent).

Nilai t hitung diperoleh dengan rumus :

$$
\mathrm{t}=\frac{\mathrm{bi}}{\mathrm{Se}(\mathrm{bi})}
$$

Dimana :

$\mathrm{t} \quad=\mathrm{t}$ hitung

bi $\quad=$ Koefisien variabel independent ( bebas )

Se $(\mathrm{bi})=$ Standar error dari variabel independent $($ bebas $)$

Nilai t hitung $>\mathrm{t}$ tabel,maka Ho ditolak,artinya ada pengaruh nyata terhadap produksi.Dan apabila nilai $\mathrm{t}$ hitung $<\mathrm{t}$ tabel,maka Ho diterima,artinya tidak berpengaruh nyata terhadap produksi.

Model analisis kedua yang digunakan untuk menjawab masalah ketiga adalah model analisis SWOT. Model ini digunakan untuk menganalisis prospek pengembangan industri Sirup kayu manis, dengan terlebih dahulu mengedentifiasi kekuatan dan kelemahan yang terdapat pada industri kecil Sirup kayu manis.Kemudian juga akan menganalisis peluang dan pengembangan.

\section{HASIL DAN PEMBAHASAN}

Analisis ini menggunakan metode regresi linier berganda, data yang digunakan secara time series yaitu dalam kurun waktu 2003 - 2018 dengan jumlah distribusi frekuensi sebanyak 16 tahun maka di peroleh hasil estimasi sebagai berikut:

Tabel 1. Hasil Persamaan regresi linier berganda

\begin{tabular}{crrrr}
\hline Variable & Coefficient & Std. Error & t-Statistic & Prob. \\
\hline C & 11.46848 & 0.237236 & 48.34205 & 0.0000 \\
PE & 0.000736 & 0.029368 & 0.025068 & 0.0094 \\
INF & 0.005692 & 0.019399 & 0.293433 & 0.0342 \\
SBI & -0.045735 & 0.029932 & -1.527996 & 0.0424 \\
\hline \hline
\end{tabular}

R-squared

0.618251 Mean dependent var

11.18576

Adjusted R-squared

0.147813 S.D. dependent var

0.137104

S.E. of regression

0.126566 Akaike info criterion

$-1.083787$

Sum squared resid

0.192228 Schwarz criterion

$-0.890639$ 


\begin{tabular}{lllr} 
Log likelihood & 12.67029 & Hannan-Quinn criter. & -1.073896 \\
F-statistic & 3.867258 & Durbin-Watson stat & 0.598502 \\
Prob(F-statistic) & 0.007438 & & \\
\hline
\end{tabular}

Sumber: Data diolah 2020

Dari hasil estimasi di atas dapat dituliskan persamaaan sebagai berikut :

$\log (\mathrm{UMKM})=11.46848+0.000736$ PE +0.005692 INF -0.045735 SBI

\section{Uji statistik}

\section{Uji simultan (uji F)}

Demikian uji f statistik dengan jumlah distribusi frekuensi sebanyak 16 tahun dengan tingkat signifikansi sebesar 95 persen maka di ketahui nilai probabilitas $\mathrm{f}$ statistik sebesar 0,007438 $<0,05$ persen, maka Ho ditolak dan Ha di terima. Artinya bahwa semua koefisien regresi atau semua variabel independen yaitu pertumbuhan ekonomi, inflasi dan suku bunga Indonesia secara bersama - sama berpengaruh terhadap pertumbuhan UMKM di Provinsi Jambi.

\section{Uji parsial (uji t)}

Tingkat signifikansi sebesar 95 persen maka di ketahui nilai probabilitas t statistik sebesar 0,094 $<0,05$ persen, maka Ho ditolak dan Ha di terima artinya variabel pertumbuhan ekonomi berpengaruh signifikan terhadap pertumbuhan UMKM di Provinsi Jambi.

Tingkat signifikansi sebesar 95 persen maka di ketahui nilai probabilitas t statistik sebesar 0,0342 < 0,05 persen, maka Ho ditolak dan Ha di terima artinya variabel inflasi berpengaruh signifikan terhadap pertumbuhan UMKM di Provinsi Jambi.

Tingkat signifikansi sebesar 95 persen maka diketahui nilai probabilitas $\mathrm{t}$ statistik sebesar 0,0424<0,05 persen, maka Ho ditolak dan Ha di terima artinya variabel suku bunga Indonesia berpengaruh signifikan terhadap pertumbuhan UMKM di Provinsi Jambi.

\section{Koefisien determinasi $\left(\mathbf{R}^{2}\right)$}

Uji ini digunakan untuk mengetahui berapa persen variasi variabel dependen yang bisa dijelaskan variabel independen. Dari hasil regresi diketahui bahwa nilai $\mathrm{R}^{2}$ adalah 0,618251 sehingga dapat katakan bahwa 61.82 persen pertumbuhan UMKM di Provinsi Jambi dijelaskan oleh variabel pertumbuhan ekonomi, inflasi dan suku bunga indonesia. Sedangkan sisanya 38.18 persen di jelaskan faktor lain diluar penelitian.

\section{KESIMPULAN DAN SARAN}

\section{Kesimpulan}

Perkembangan UMKM tahun 2003 - 2018 meningkat rata - rata sebesar 2.40 persen, peningkatan tertinggi pada tahun 2010 dan penurunan tertinggi pada tahun 2007. Perkembangan pertumbuhan ekonomi tahun 2003 - 2018 meningkat rata - rata sebesar 6.20 persen, peningkatan tertinggi pada tahun 2011 dan peningkatan terendah tahun 2015. Perkembangan inflasi tahun 2003 - 2018 rata - rata sebesar 7.67 persen tertinggi pada tahun 2005 dan terendah 2018. Perkembangan suku bunga Indonesia tahun 2003 - 
2018 rata - rata sebesar 2.79 persen, peningkatan tertinggi pada tahun 2005 dan penurunan tertinggi tahun 2009. Hasil estimasi menggunakan uji f statistik menunjukan bahwa semua variabel yaitu pertumbuhan ekonomi, inflasi dan suku bunga Indonesia secara bersama - sama berpengaruh terhadap pertumbuhan UMKM di Provinsi Jambi, dengan uji t statistik menunjukan bahwa variabel pertumbuhan ekonomi berpengaruh signifikan terhadap pertumbuhan UMKM di Provinsi Jambi, inflasi berpengaruh signifikan terhadap pertumbuhan UMKM di Provinsi Jambi dan suku bunga Indonesia berpengaruh signifikan terhadap pertumbuhan UMKM di Provinsi Jambi.

\section{Saran}

Salah satu faktor yang mendukung dalam pertumbuhan UMKM di Provinsi Jambi yaitu pertumbuhan ekonomi semakin besar pertumbuhan ekonomi suatu daerah maka akan meningkatkan investasi pada sektor UMKM, sehingga perhatian pada UMKM dapat diberikan dengan meningkatkan investasi pada UMKM, menjaga kestabilan harga dan suku bunga, dengan langkah tersebut dapat berupa perbaikan iklim usaha dan permudahan izin usaha dalam investasi. Dalam meningkatkan pertumbuhan UMKM maka pemerintah Provinsi Jambi atau pihak Bank atau lembaga non keuangan seharusnya lebih memprioritaskan untuk meminjamkan modal kepada para pengusaha mikro sehingga dapat mengembangkan usahanya dengan mudah yang sumber modalnya selain bersumber pada modal sendiri dan juga dapat bersumber dari luar seperti Bank Pemerintah yang membantu usaha tersebut dalam memperoleh pinjaman dengan syarat yang tertentu tetapi harus terlebih dahulu diberikan pengetahuan tentang pembukuan sederhana sehingga modal yang disalurkan benar-benar dimanfaatkan untuk usaha.

\section{DAFTAR PUSTAKA}

Amir, Amri; Junaidi dan Yulmardi. (2009). metodologi penelitian ekonomi dan penerapannya. IPB PRESS: Bogor.

Badan Pusat Statistik, (2003 - 2017). Penyerapan tenaga kerja Jambi dalam angka 2010. BPS: Jambi

Departemen Perindustrian dan Pedagangan. 2015) Faktor-faktor yang mempengaruhi tenaga kerja. DISPERINDAG: Jambi

Gujarati, Damodar. (2003). Ekonometrika dasar. Erlangga: Jakarta.

Herlan Firmansyah, dkk. (2014). Advanced learning economics 2 for Grade XI Social Sciences Programme, Grafindo Media Pratama: Bandung, Hal 149-150.

Iskandar Putong. (2003). Pengantar ekonomi mikro dan makro, Ghalia Indonesia: Jakarta, Hal. 254-255

Iswandi, Ismi, (2000). Pengembangan industri kecil dan rumah tangga. Kasmir:Jakarta Jhingan ML. (2004). Ekonomi pembangunan dan perencanaan. Rajawali,Press: Jakarta

Junaidi,J; Z Zulfanetti, \& H Hardiani. (2014). Analisis kondisi ketenagakerjaan di Provinsi Jambi. Fakultas Ekonomi dan Bisnis Universitas Jambi: Jambi

Kartasapoetra G. (2000). Makro ekonomi, Edisi Kedua, Cetakan Keempat Belas. Raja Grafindo Persada: Jakarta.

Mulyadi,A; H Hardiani; \& E Umiyati. (2018). Faktor-faktor yang mempengaruhi penyerapan tenaga kerja pada sektor industri kecil di Kabupaten Muaro Jambi, e-Jurnal Perdagangan Industri dan Moneter 6 (1), 35-44 
Partomo, T.S dan Soejoedono, A.R. (2004). Ekonomi skala kecil/menengah dan koperasi. Galia Indonesia: Bogor.

Subri, Mulyadi. (2003). Ekonomi sumber daya manusia. PT Raja Grafindo Persada:Jakarta

Sudarsono dkk. (1988). Ekonomi sumber daya manusia, Karunia Universitas Terbuka: Jakarta: Jakarta

Sukirno, Sadono. (2003). Ekonomi pembangunan (proses, masalah, dan kebijakan). Kencana Prenada: Jakarta.

Sumarsono. (2009). Ekonomi sumber daya manusia teori dan kebijakan publik. Graha Ilmu: Jogyakarta

Sunargo,S; \& D Hastuti. (2019).Mengatasi perilaku kerja kontraproduktif melalui peran integratif politik organisasional dan kecerdasan emosional pada era revolusi industri 4.0, Jurnal Paradigma Ekonomika 14 (2), 45-54

Tambunan, Tulus. (2002). Usaha kecil dan menengah di Indonesia: Beberapa Isu Penting. Salemba Empa: Jakarta

Todaro, Micheal. (2003). Pembangunan ekonomi di dunia ketiga. Airlangga: Jakarta

Yustini. (2015). Pengaruh suku bunga dan pertumbuhan ekonomi terhadap jumlah UMKM di Sumatera Selatan. Jurnal Ekonomi, 19(3), 463-474. 